\title{
THE EXPRESSION OF E6 HPV, p53 AND p16INK4A AT WELL, MODERATELY, AND POORLY DIFFERENTIATED CERVICAL ADENOCARCINOMA
}

\author{
Gondo Mastutik ${ }^{1}$, Alphania Rahniayu ${ }^{1,2}$, Nila Kurniasari ${ }^{1,2}$, Anny Setijo Rahaju ${ }^{1,2}$, Rahmi Alia ${ }^{3}$, \\ Sjahjenny Mustokoweni, ${ }^{1,2}$ \\ ${ }^{1}$ Department of Anatomic Pathology, Faculty of Medicine, Universitas Airlangga, Surabaya, ${ }^{2}$ Dr. Soetomo General \\ Academic Hospital, Surabaya, ${ }^{3}$ Prof Dr Soekandar Hospital, Mojokerto, Indonesia
}

\section{ABSTRACT}

\begin{abstract}
The objective of this study is to analyze the expression of E6 Humanpapilloma virus (HPV), p53, and p16INK4A in cervical adenocarcinoma grade well differentiated (WD), moderately differentiated (MD), and poorly differentiated (PD). A cross sectional study conducted at Department of Anatomic Pathology, Dr. Soetomo General Academic Hospital Surabaya Indonesia using formalin fix paraffin embedded (FFPE) from cervical normal and cervical adenocarcioma grade WD, MD, and PD. The expression of E6 HPV, p53, and p16INK4A was performed by immunohistochemistry (IHC) staining. Data were analyzed with Kruskal-Wallis and continued with Mann-Withney test. The expression of E6 HPV in the cervical adenocarcinoma showed 35.9\% specimens represented negative and $64.1 \%$ specimens represented positive. There was no significant difference in the expression of E6 HPV and p53 in cervical adenocarcinoma between grade WD, MD, and PD. The p16INK4A was overexpressed, shown as diffuse appearance in $89.7 \%$ of the specimens. There was a significant difference in the expression of p16INK4A between grade WD and MD with PD. In conclusion, some of cervical adecarcinoma were not caused by infection of HPV type 16 or 18 and the expression of p16INK4A might take a role in the developing of malignancy that caused by infection of $H P V$.
\end{abstract}

Keywords: Grading of cervical adenocarcinoma; E6 HPV; p53; p16INK4A

\section{ABSTRAK}

Tujuan penelitian ini adalah menganalisa ekspresi E6 Humanpapilloma virus (HPV), p53,dan p16INK4A pada adenocarcinoma servik grade well differentiated (WD), moderately differentiated (MD), dan poorly differentiated (PD). Penelitian cross sectional dilaksanakan di Departemen Patologi Anatomik, Rumah Sakit Umum Pendidikan Dr. Soetomo Surabaya Indonesia menggunakan blok paraffin (BP) dari jaringan serviks normal dan adenocarcioma servik grade WD, MD, dan PD. Evaluasi ekspresi E6 HPV, p53, dan pl6INK4A dilakukan dengan pewarnaan immunohistochemistry (IHC). Data dianalisa dengan Kruskal-Wallis kemudian dilanjutkan dengan Mann-Withney test. Ekspresi E6 HPV pada adenocarcinoma servik menunjukkan 35.9\% specimen adalah negatif dan $64.1 \%$ specimen adalah positif. Tidak terdapat perbedaan yang nyata ekspresi of E6 HPV dan p53 pada adenocarcinoma servik antara grade WD, MD, dan PD. Terjadi overekspresi p16INK4A, yang menunjukkan sebaran merata pada $89.7 \%$ dari spesimen. Terdapat perbedaan yang nyata pada ekspresi p16INK4A antara grade WD dan MD dengan PD. Kesimpulan, beberapa specimen adecarcinoma serviks tidak disebabkan oleh infeksi HPV 16 atau HPV 18 dan ekspresi p16INK4A mungkin berperan dalam perkembangan keganasan servik yang disebabkan oleh infeksi HPV.

Kata kunci: Grade adenocarcinoma servik; E6 HPV; p53; p16INK4A

Correspondence: Gondo Mastutik, Department of Anatomic Pathology, Faculty of Medicine, Universitas Airlangga, Jl. Prof Dr Moestopo 47, Surabaya 60132, Indonesia, E-mail: gondomastutik@fk.unair.ac.id, gondomastutik@gmail.com

pISSN:2355-8393 • eISSN: 2599-056x • doi: http://dx.doi.org/10.20473/fmi.v55i4.17327

- Fol Med Indones. 2019;55:295-300 • Received 24 May 2019 • Accepted 28 Nov 2019

- Open access under CC-BY-NC-SA license • Available at https://e-journal.unair.ac.id/FMI/

\section{INTRODUCTION}

Cervical cancer is the fourth most common cancer diagnosed in women worldwide. In Indonesia, it is the second most common cancer diagnosed in women after breast cancer, with an estimated 20,928 new cases and 4,097 deaths in 2012 (Ferlay et al 2013). Based on the histological classification of tumours, the most common type of cervical cancer is squamus cell carcinoma (Wells et al 2003) and cervical adenocarcinoma comprises $15 \%$ of cervical cancer cases (Siriaunkgul et al 2013). The incidence rates of cervical adenocarcinoma tend to increase in Korean women (Oh et al 2013), in women in the United States (Adegoke et al 2012), and in the Netherlands where it is found predominantly in women of 25-39 years old (van der 
Horst et al 2017). This trend is particularly evident among females aged $<40$ years and has occurred despite extensive cytology-based screening programs (Tornesello et al 2014). Adenocarcinoma originates from glandular precursor lesions of the endocervical mucosa that are difficult ro reach by pap smear examination. Therefore, although screening programs have led to a substantial decrease in the incidence of squamus cell carcinoma (Andersson et al 2013), it is not protective for precursor cancer whose cells cannot be reached by screening programs, including cervical adenocarcinoma.

Humanpapilloma virus (HPV) has already been established as the cause of cervical cancer and it is related to other anogenital cancers (anus, vulva, vagina and penis) as well as head and neck cancers. HPV types 16 and 18 are responsible for about $70 \%$ of all cervical cancer cases worldwide (Bruni et al 2017). The E6 and E7 of the high risk HPV have associated with oncogenic transformation. E6 interacts with the product of tumour suppressor genes p53. It targets p53 for degradation via ubiquitin pathway, resulting in loss of G2/M checkpoint regulation. In addition, degradation of p53 by E6 HPV leads to irreversible DNA damage and the cells enter the cell cycle and cease to apoptose, resulting in the accumulation of genomic instability and genetic alteration. E7 interacts with retinoblastoma (RB) family member RB1, RBL1, and RBL2, then targets them for degradation, resulting in nuclear translocation of $\mathrm{E} 2 \mathrm{~F}$ and promotion of $\mathrm{S}$-phase transition. The result of $\mathrm{pRb}$ downregulation of the loss of feedback inhibition and overexpression of p16INK4A (Scheffner et al 1990, Hietanen et al 2000, Crosbie et al 2013).

During the progression of cervical adenocarcinoma, cells differentiate into well-differentiated (WD), moderately-differentiated (MD), or poorly-differentiated (PD). However, the expression of p53 and p16INK4A in cervical adenocarcinoma grade WD, MD, PD is still not clear. The objective of this study was to analyze the expression of E6, p53, and p16INK4A in cervical adenocarcinoma grade $\mathrm{WD}, \mathrm{MD}$, and $\mathrm{PD}$.

\section{MATERIALS AND METHODS}

\section{Specimens}

This was a cross sectional study conducted at the Department of Anatomic Pathology, Dr. Soetomo General Academic Hospital Surabaya Indonesia. The specimens were cervices from the uterine prolapse cases and adenocarcinoma cases that had been diagnosed by pathologist. There were 10 formalin fix paraffin embedded (FFPE) of the uterine prolapse as control group and 39 FFPE of cervical adenocarcioma that consisted of 14 tissues were grade WD, 12 tissues were grade MD, and 13 tissues were grade PD.

\section{Immunohistochemistry staining}

The expressions of E6 HPV, p53, and p16INK4A are detected by immunohistochemistry (IHC) staining using the HPV16 E6/18 E6 Antibody (C1P5): sc-460 (Santa Cruz Biotechnology), monoclonal antibody p53 clone Y5 (Biocare), and Anti-CDKN2A/ p16INK4A Antibody (clone 1E12E10) IHC-plus ${ }^{\text {TM }}$ LS-B5261 (LS Bio).

The scoring of the positive interpretation for E6 HPV is performed when the nucleus and cytoplasm were stained clearly and scored using an arbitrary semiquantitative scale. Score 0 is given when there are no cells stained representing negative staining, score 1 when $5-25 \%$ of the cells stained representing mild positive staining, score 2 when $25-50 \%$ of the cells stained representing moderate positive staining, and score 3 when $>50 \%$ of the cells stained representing extensive immunostaining (Chaudhary et al 2013).

Expression of p53 is evaluated when the nucleus is stained clearly and scored semiquantitatively. The score is 0 if up to $5 \%$ of the cells are positive, score 1 if 5$25 \%$ of the cells are positive, score 2 if $26-50 \%$ of the cells are positive, score 3 if 51-75\%, and score 4 if more than $75 \%$ of the cells are positive (Baalbergen et al 2013).

Expression of p16INK4A is evaluated as positive when nuclear or cytoplasmic immunostaining is clearly demonstrated. Scoring of p16INK4A is performed using the criteria of Klaes et al. (2001). In this scoring, score 0 is given if there is no staining or $<1 \%$ of the cells are positively representing negative, score 1 if $1-5 \%$ of the cells positively representing sporadic, score 2 if $5-25 \%$ of the cells are positively representing focal, and score 3 if $>25 \%$ of the cells are positively representing diffuse (Kazlouskaya et al 2013).

\section{Statistical analysis}

To evaluate different expression of E6 HPV, p53 and p16INK4A at normal cevix tissue and cervical adenocarcinoma tissue based on differentiated grading, the analysis was performed by using The KruskalWallis $(\mathrm{p}<0.005)$ and continued with Mann Withney test $(\mathrm{p}<0.005)$.

\section{RESULTS}

This study was performed to cervix specimen of 49 women with ages $30-81$ years old and average $51.78 \pm$ 
9.395 (mean + SD). There were 20.4\% FFPE from cervical normal and $79.6 \%$ from cervical adenocarcioma that consisted of $35.9 \%, 30.8 \%$, and $33.3 \%$ FFPE from WD, MD, and PD tissues, respectively.

The expression of E6 HPV, p53, and p16INK4A in cervical adenocarcinoma grade WD, MD, and PD showed in IHC staining (Figure 1). The expression of E6 HPV in the cervical adenocarcinoma showed that those with score 0 were $14(35.9 \%)$ specimens, score 1 were $11(28.2 \%)$, score 2 were $11(28.2 \%)$, and score 3 were $3(7.7 \%)$. The expression of E6 HPV in cervical adenocarcinoma in grade $\mathrm{WD}, \mathrm{MD}$, and $\mathrm{PD}$ have the same "a" subscript (Table 1). It means that there was no significant difference in the expression of E6 HPV between cervical adenocarcinoma in grade WD, MD, and PD.

Expression of p53 in the cells of cervical adenocarcinoma WD, MD, and PD showed that those with score 0 were $12(30.8 \%)$, score 1 were $15(38.5 \%)$, score 2 were $3(7.7 \%)$, score 3 were $4(10.2 \%)$, and score 4 were 5 $(12.8 \%)$. The result showed that there was no significant difference in the expression of p53 between cervical adenocarcinoma grade WD, MD, and PD ( $>>0,05)$ (Table 1). Expression of p16INK4A in cervical adenocarcinoma grade WD, MD, and PD showed that almost all of the specimens were positively diffuse (score 3) and there was no negative (Fig. 1). The result showed that there was a significant difference in the expression of p16INK4A between cervical adenocarcinoma in grade WD and MD with PD (Table 1).

\section{DISCUSSION}

Chronic infection of HPV is correlated with the development of cervical carcer (Wells et al 2003). HPV 16, 18 are the most common genotypes of HPV that are presenting in cervical adenocarcinoma (An et al 2005, Tornesello et al 2011, Siriaunkgul et al 2013). In Korean women, the prevalence of HPV infection in cervical adenocarcinoma was $90 \%$. The infection of HPV 16 and/or HPV 18 accounted for $78 \%$ of HPVpositive adenocarcinomas. Multiple HPV types were found in $13 \%$ of the cases. Mostly HPV 16 and HPV 18 are highly associated with most of cervical adenocarcinomas (An et al 2005). In Thailand, predominant genotype is HPV 18, being twice as common as HPV 16 (Siriaunkgul et al 2013). In Uppsala Sweden, 95\% were HR HPV positive; HPV18/45 predominated (77\%), followed by HPV16 (27\%) (Andersson et al 2013). In the Netherlands, HPV1 8 is mainly the risk factor for the development of adenocarcinoma, while HPV16 is associated with both SCC and adenocarcinoma (Bulk et al 2006). Because of that in this study we used the E6 of HPV 16 and HPV 18.

Table 1. Different expression of E6 HPV, p53, and p16INK4A at cervical normal and well differentiated, moderately differentiated, and poorly differentiated adenocarcinoma

\begin{tabular}{|c|c|c|c|c|c|c|}
\hline E6 & $\mathrm{AWD}^{\mathrm{a}}$ & $\mathrm{AMD}^{\mathrm{a}}$ & $\mathrm{APD}^{\mathrm{a}}$ & $\mathrm{CN}^{\mathrm{b}}$ & Total & $\mathrm{p}=0.001$ \\
\hline 0 & $4(28.6 \%)$ & $5(41.7 \%)$ & $5(38.5 \%)$ & $10(100 \%)$ & $24(49 \%)$ & \\
\hline 1 & $6(42.9 \%)$ & $2(16.7 \%)$ & $3(23.1 \%)$ & $0(0 \%)$ & $11(22.4 \%)$ & \\
\hline 2 & $2(14.3 \%)$ & $5(41.7 \%)$ & $4(30.8 \%)$ & $0(0 \%)$ & $11(22.4 \%)$ & \\
\hline 3 & $2(14.3 \%)$ & $0(0 \%)$ & $1(7.7 \%)$ & $0(0 \%)$ & $3(6.1 \%)$ & \\
\hline p53 & AWD & AMD & APD & $\mathrm{CN}$ & & $\mathrm{p}=0.179$ \\
\hline 0 & $4(28.6 \%)$ & $3(25 \%)$ & $5(38.5 \%)$ & $6(60 \%)$ & $18(36.7 \%)$ & \\
\hline 1 & $6(42.9 \%)$ & $4(33.3 \%)$ & $5(38.5 \%)$ & $3(30 \%)$ & $18(36.7 \%)$ & \\
\hline 2 & $1(7.1 \%)$ & $1(8.3 \%)$ & $1(7.7 \%)$ & $1(10 \%)$ & $4(8.2 \%)$ & \\
\hline 3 & $1(7.1 \%)$ & $1(8.3 \%)$ & $2(15.4 \%)$ & $0(0 \%)$ & $4(8.2 \%)$ & \\
\hline 4 & $2(14.3 \%)$ & $3(25 \%)$ & $0(0 \%)$ & $0(0 \%)$ & $5(10.2 \%)$ & \\
\hline $\mathrm{p} 16^{\mathrm{INK} 4 \mathrm{~A}}$ & $\mathrm{AWD}^{\mathrm{a}}$ & AMD $^{a}$ & $\mathrm{APD}^{\mathrm{b}}$ & $\mathrm{CN}^{\mathrm{c}}$ & & $\mathrm{p}=<0.0001$ \\
\hline 0 & $0(0 \%)$ & $0(0 \%)$ & $0(0 \%)$ & $9(90 \%)$ & $9(18.4 \%)$ & \\
\hline 1 & $0(0 \%)$ & $0(0 \%)$ & $1(7.7 \%)$ & $1(10 \%)$ & $2(4.1 \%)$ & \\
\hline 2 & $0(0 \%)$ & $0(0 \%)$ & $3(23.1 \%)$ & $0(0 \%)$ & $3(6.1 \%)$ & \\
\hline 3 & $14(100 \%)$ & $12(100 \%)$ & $9(69.2 \%)$ & $0(0 \%)$ & $35(71.4 \%)$ & \\
\hline
\end{tabular}




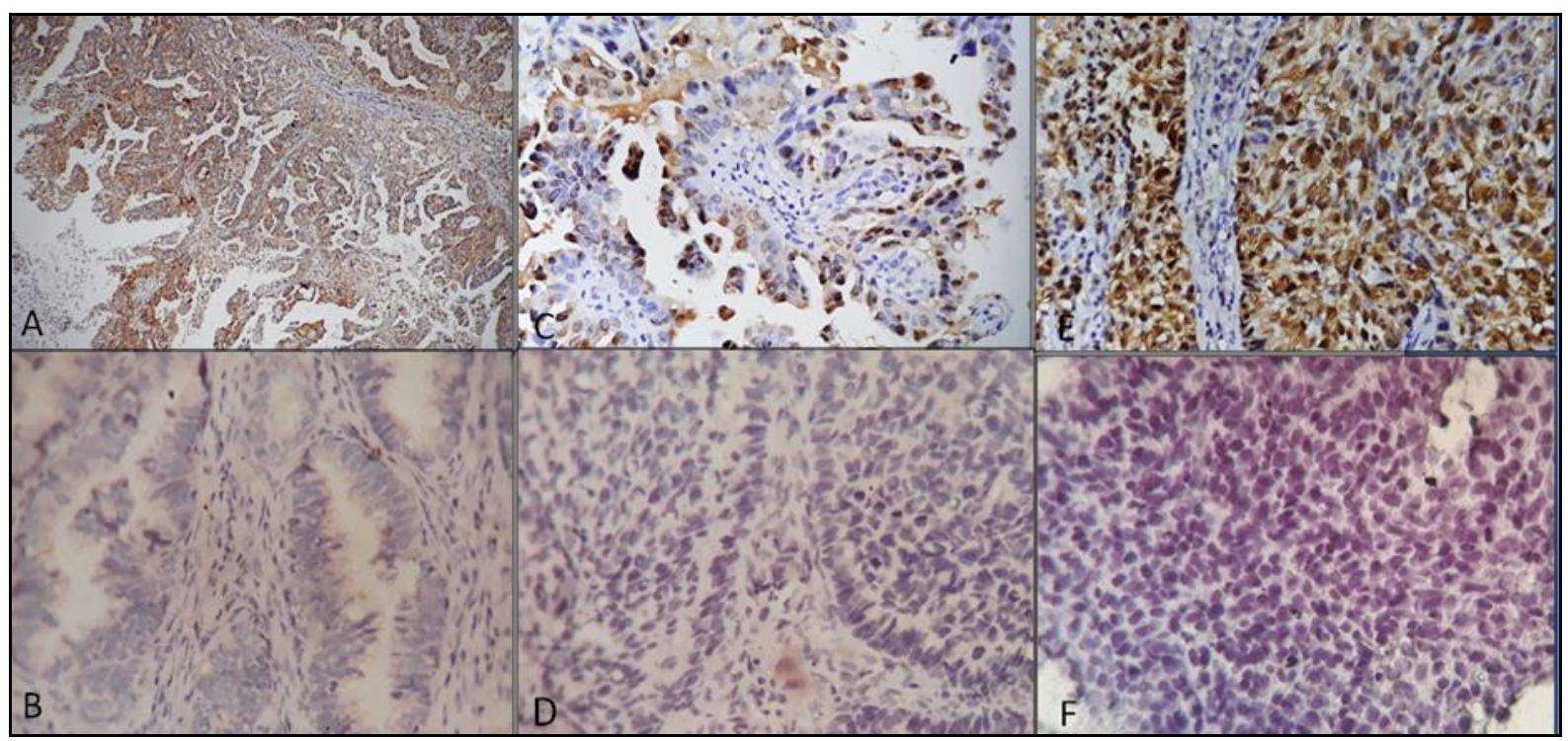

Fig. 1. Expression of E6 HPV, p53, and p16INK4A in cervical adenocarcinoma grade well differentiated (WD), moderately differentiated (MD), poorly differentiated (PD). A. Expression E6 HPV, positive in adenocarcinoma WD, 100X; B. Expression E6 HPV, negative in adenocarcinoma WD, 400X; C. Expression p53, positive in adenocarcinoma MD, 400X; D. Expression p53, negative in adenocarcinoma MD, 400X; E. Expression p16INK4A, positive in adenocarcinoma PD, 400X; F. Expression p16INK4A, negative in adenocarcinoma PD, 400X.

The histology of cervical adenocarcinoma exhibits a variety of architectural patterns and ranges from WD, $\mathrm{MD}$, and PD. The WD of cervical adenocarcinoma may show exophytic papillary growth or infiltrative growth, or both. The invasive tumor may be composed of irregular cystic and tubular glands, glands with intraluminal papillary infoldings, or cribriform glands. In the MD tumors the growth is more confluent with sheets of small cribriform glands. The poorly differentiated adenocarcinomas show solid areas of undifferentiated cells that may be undistinguishable from poorly differentiated squamous cell carcinoma (Pirog, 2017). This grading change occurs along with the development of malignancy so that it will affect the expression of tumor suppessor gene, p53 and p16INK4A.

E6 HPV in this study represented the infection of HPV 16 and or 18 (HPV 16/18), showed that $35.9 \%$ and $64.1 \%$ specimens of cervical adenocarcinoma represented negative and positive for E6 HPV 16/18, respectively. This suggested that some of cervical adecarcinoma tissues were not infected by HPV type 16 or 18 , so it might be related with other HPV types or any others causes. This study was in accordance with other study that the prevalence of HPV in cervical adenocarcinoma varied from 62 to $100 \%$, depending on geographic region and tumor subtype (Baalbergen et al 2013). The expression of E6 HPV in cervical adenocarcinoma between grade WD, MD, and PD, there are no significant different. This data suggested that the infection of HPV type 16 or 18 did not affect the grading differentiation of cervical adenocarcinoma.

This study showed that the score 0 for the expression of p53 in the cells of cervical adenocarcinoma grade WD, $\mathrm{MD}$, and PD was $30.8 \%$, and score $1,2,3$, and 4 were $69.2 \%$. It suggests that some specimens have not and have shown the expression of p53. The wild type p53 has half-life of about 5-20 minutes (Dowell et al 1994) and then degardated, whereas the E6 HPV 16 and 18 binds to p53 and also stimulate degradation (Crosbie et al 2013), so it would be negative for IHC staining. The unbiquitin form of p53 as result of degradation by E6 HPV and mutant type p53 should be positive by IHC staining. Other studies showed that the mutation of p53 gene in cervical adenocarcinoma is more frequent than that in squamous cell carcinoma or cervical intraepithelial neoplasia. There is a single nucleotide substitutions in p53 gene detected in 36\% cervical adenocarcinoma cases and this mutation is independent from HPV infection status (Tornesello et al 2014). In cervical adenocarcinoma, the positivity of p53 is associated with poor survival. The survival rate in cervical adenocarcinoma is $67 \%$, and it is not influenced by estrogen receptor, progesterone receptor, MIB-1, or bcl-2 with strongly positive staining, but significantly influenced by the expression of p53. The p53 staining is 
strongly positive. The survival is significantly worse than that in tumors scored as negative or weak positive (Baalbergen et al 2013).

This study found that the expression of p16INK4A was overexpressed in cervical adenocarcinoma grade WD, MD, and PD. This was demonstrated by the diffuse appearance in $89.7 \%(35 / 39)$ of the specimens. It was also showed that a significant difference in the expression of p16INK4A in cervical adenocarcinoma between grade WD and MD with PD. The expression of p16INK4A in WD and MD was diffusely positive. This result was the same with the finding in other study that p16INK4A was expressed in diffusely or strongly expression in cervical intraepithelial neoplasia I, II, III, squamous cell carcinoma, endocervical glandular dysplasia, adenocarcinoma in situ, and invasive adenocarcinoma (Tringler B et al 2004); as well as in endocervical carcinoma (Liang et al 2016). The finding in this study was in accordance with the results of other studies. The overexpression of p16INK4A in uterine cervix adenocarcinoma is common and significantly associated with HPV infection (mainly high-risk HPV types). It suggests that p16INK4A is a putative molecular biomarker that consistently discriminates uterine cervix adenocarcinomas from benign lesions and from endometrioid adenocarcinomas of the uterine corpus (Missaoui et al 2006). The overexpression of the p16INK4A was typical for dysplastic and neoplastic epithelia of the uterine cervix. The expression of p16 increases from normal to invasive squamous carcinoma in the uterine cervix emphasizing that it might be a useful marker for predicting risk of developing cervical cancer in women (Izadi-Mood et al 2012).

\section{CONCLUSION}

There was no significant difference in the expression of E6 HPV and p53 in cervical adenocarcinoma between grade $\mathrm{WD}, \mathrm{MD}$, and $\mathrm{PD}$, but there was a significant difference in the expression of p16INK4A between grade $\mathrm{WD}$ and $\mathrm{MD}$ with $\mathrm{PD}$. This finding suggest that the expression of p16INK4A might take a role in the developing of maliganacy that caused by infection HPV.

\section{ACKNOWLEDGMENT}

This study was supported by the Ministry of Research, Technology, and Higher Education of the Republic of Indonesia by the university operational funding fiscal years at 2017. Thank you for the Indonesian Government and the Faculty of Medicine Airlangga University.

\section{REFERENCES}

Adegoke O, Kulasingam S, Virnig B (2012). Cervical cancer trends in the United States: a 35-year population-based analysis. J Womens Health (Larchmt) 21, 1031-7

An HJ, Kim KR, Kim IS, et al (2005). Prevalence of human papillomavirus DNA in various histological subtypes of cervical adenocarcinoma: a populationbased study. Mod Pathol 18, 528-34

Andersson S, Mints M, Wilander E (2013). Results of cytology and high-risk human papillomavirus testing in females with cervical adenocarcinoma in situ. Oncol Lett 6, 215-9

Baalbergen A, Smedts F, Ewing P, et al (2013). HPVtype has no impact on survival of patients with adenocarcinoma of the uterine cervix. Gynecol Oncol 128, 530-4

Bruni L, Barrionuevo-Rosas L, Albero G, et al 2017. Human Papillomavirus and Related Diseases in Indonesia. Summary Report 27 July 2017 [Online]. ICO/IARC Information Centre on HPV and Cancer (HPV Information Centre) 2017. Accessed April 12, 2018

Bulk S, Berkhof J, Bulkmans NW, et al (2006). Preferential risk of HPV16 for squamous cell carcinoma and of HPV18 for adenocarcinoma of the cervix compared to women with normal cytology in The Netherlands. Br J Cancer 94, 171-5

Chaudhary A, Pandya S, Singh M, et al (2013). Identification of high-risk human papillomavirus-16 and -18 infections by multiplex PCR and their expression in oral submucous fibrosis and oral squamous cell carcinoma. Head and Neck Oncology 5, $1-10$

Crosbie EJ, Einstein MH, Franceschi S, et al (2013). Human papillomavirus and cervical cancer. The Lancet 382, 889-99

Dowell SP, Wilson PO, Derias NW, et al (1994). Clinical utility of the immunocytochemical detection of p53 protein in cytological specimens. Cancer Res 54, 2914-8

Hietanen S, Lain S, Krausz E, et al (2000). Activation of p53 in cervical carcinoma cells by small molecules. Proc Natl Acad Sci U S A, 97, 8501-6

Izadi-Mood N, Asadi K, Shojaei H, et al (2012). Potential diagnostic value of P16 expression in premalignant and malignant cervical lesions. J Res Med Sci 17, 428-33

Kazlouskaya V, Shustef E, Allam SH, et al (2013). Expression of p16 protein in lesional and perilesional condyloma acuminata and bowenoid papulosis: clinical significance and diagnostic implications. J Am Acad Dermatol 69, 444-9

Klaes R, Friedrich T, Spitkovsky D, Ridder R, Rudy W, Petry U, et al. (2001). Overexpression of p16INK4A 
as a specific marker for dysplastic and neoplastic epithelial cells of the cervix uteri Int J Cancer 2001 92, 276-84

Liang L, Zheng W, Liu J, et al (2016). Assessment of the Utility of PAX8 Immunohistochemical Stain in Diagnosing Endocervical Glandular Lesions. Arch Pathol Lab Med, 140, 148-52

Missaoui N, Hmissa S, Frappart L, et al (2006). p16INK4A overexpression and HPV infection in uterine cervix adenocarcinoma. Virchows Arch 448, 597-603

Oh CM, Jung KW, Won YJ, et al (2013). Trends in the incidence of in situ and invasive cervical cancer by age group and histological type in Korea from 1993 to 2009. PLoS One 8, e72012

Pirog EC (2017). Cervical Adenocarcinoma: Diagnosis of Human Papillomavirus-Positive and Human Papillomavirus-Negative Tumors. Arch Pathol Lab Med 141, 1653-67

Scheffner M, Werness BA, Huibregtse JM, et al (1990). The E6 oncoprotein encoded by human papillomavirus types 16 and 18 promotes the degradation of p53. Cell 63, 1129-36
Siriaunkgul S, Utaipat U, Suthipintawong C, et al (2013). HPV genotyping in adenocarcinoma of the uterine cervix in Thailand. Int J Gynaecol Obstet 123, 226-30

Tornesello ML, Annunziata C, Buonaguro L, et al (2014). TP53 and PIK3CA gene mutations in adenocarcinoma, squamous cell carcinoma and highgrade intraepithelial neoplasia of the cervix. J Transl Med, 12, 255

Tornesello ML, Losito S, Benincasa G, et al (2011). Human papillomavirus (HPV) genotypes and HPV16 variants and risk of adenocarcinoma and squamous cell carcinoma of the cervix. Gynecol Oncol, 121, 3242

van der Horst J, Siebers AG, Bulten J, et al (2017). Increasing incidence of invasive and in situ cervical adenocarcinoma in the Netherlands during 2004-2013. Cancer Med, 6, 416-23

Wells M, Östör AG, Crum CP, et al (2003). Tumours of the uterine cervix, epithelial tumours. In 'Pathology and Genetics of Tumours of the Breast and Female Genital Organs', Eds IARCPress, Lyon, 259-72 